University of Miami Law School University of Miami School of Law Institutional Repository

1996

\title{
Observations on Vessel Release under the United Nations Convention on the Law of the Sea
}

Bernard H. Oxman

University of Miami School of Law, bhoxman@law.miami.edu

Follow this and additional works at: https://repository.law.miami.edu/fac_articles

Part of the Law of the Sea Commons

\section{Recommended Citation}

Bernard H. Oxman, Observations on Vessel Release under the United Nations Convention on the Law of the Sea, 11 Int'l J. Marine \& Coastal L. 201 (1996).

This Article is brought to you for free and open access by the Faculty and Deans at University of Miami School of Law Institutional Repository. It has been accepted for inclusion in Articles by an authorized administrator of University of Miami School of Law Institutional Repository. For more information, please contact library@law.miami.edu. 


\title{
Observations on Vessel Release under the United Nations Convention on the Law of the Sea
}

\author{
Bernard H. Oxman* \\ Professor of Law, University of Miami School of Law
}

\begin{abstract}
If a foreign ship is detained by a coastal or port state, the flag state may contest the legality of the detention and submit the case to a court or tribunal having jurisdiction under the general dispute settlement provisions of the Convention. Article 292 sets up a more circumscribed, additional procedure for vessel release. It does not entail the submission of a dispute on the merits to a court or tribunal for judgment. The matter must be dealt with "without delay". Articles 294 and 295 are arguably not relevant. Local proceedings are unaffected and local remedies need not be exhausted. Application can be made "by or on behalf" of the flag state. The text provides an alternative. The words "on behalf of" present an option that is not already provided by the word "by". Therefore, these words should be understood to permit the flag state to dispense with the need for official communication from its government in connection with each application for release, such as is necessary for an application "by" the flag state. Instead, the state may designate in advance natural or judicial persons (e.g. owners or operators), who are authorized to bring applications for release on its behalf. Since no application for release "on behalf of the flag State" may be made against its will, the flag state may change, qualify or withdraw its designations at any time. While there is no doubt that the German Government will permit parties before the Tribunal to be represented by counsel of their choice, without regard to the country in which counsel is licensed to practise law, the question remains whether foreign counsel will be permitted to maintain an office in Hamburg even when they are not working on a case before the International Tribunal for the Law of the Sea. This is, however, less a question of Germany's international obligations, than a question of whether Germany wishes to promote the idea that Hamburg is a global centre for legal activity related to the Law of the Sea.
\end{abstract}

* The author served as US Representative to the Third United Nations Conference on the Law of the Sea and as chairman of the English Language Group of the Conference Drafting Committee, and participated in all substantive sessions of the Conference. The views expressed herein are his own.

THE INTERNATIONAL JOURNAL OF MARINE AND COASTAL LAW, Vol 11, No 2

(C) Kluwer Law International, 1996 


\section{Introduction}

The United Nations Convention on the Law of the Sea ${ }^{1}$ introduced major changes in the international law of the sea, particularly when compared with the 1958 Geneva Conventions on the Law of the Sea. Among the most important changes are the expanded competences granted to coastal states. In particular, the 200-mile exclusive economic zone represents a dramatic geographic and functional expansion of coastal state jurisdiction bringing a third of the marine environment within the limits of coastal state jurisdiction.

The expansion of coastal state competences is balanced in two ways to protect the interests of other states and the collective interests of all states. First, the Convention contains limitations on the geographic and functional scope of these competences and on the manner in which they may be exercised. Secondly, subject to certain exceptions, the Convention requires arbitration or adjudication of disputes not settled by other means.

\section{Coastal State Enforcement Competence}

Detention or arrest of foreign ships is a particularly sensitive matter. It affects the right to communicate, which is central to the security and well-being of most if not all peoples including, but by no means limited to, those of the flag state. This issue is addressed in detail in several contexts in the Convention. ${ }^{2}$ Two are of particular interest for purposes of this study. The first concerns the power of the coastal state to "take such measures, including boarding, inspection, arrest and judicial proceedings, as may be necessary to ensure compliance with the laws and regulations adopted by it" with respect to the exploration, exploitation, conservation and management of living resources in the exclusive economic zone. $^{3}$ The second concerns the power of the port state or the coastal state to enforce national or international regulations regarding pollution of the marine environment. ${ }^{4}$

1 United Nations Convention on the Law of the Sea, opened for signature 10 December 1982, UN Doc. A/CONF.62/122 (1982), reprinted in United Nations, Official Text of the United Nations Convention on the Law of the Sea with Annexes and Index, UN Sales No. E.83.V.5 (1983), and Agreement relating to the Implementation of Part XI of the Convention, opened for signature 29 July 1994, appended to GA Res. 48/263 (28 July 1994), reprinted US Senate Treaty Doc. 10339 (1994) (hereinafter cited as the Convention).

2 With some elaboration, Arts. 100-107, 110 and 111 of the Convention repeat the provisions of the 1958 Convention on the High Seas with respect to piracy, the right of visit, and hot pursuit. Convention on the High Seas, 29 April 1958, 13 UST 2312, TIAS 5200, 450 UNTS 82. A new provision is added with respect to unauthorized broadcasting from the high seas: Convention, Art. 109. Although drawn from the Convention on the Continental Shelf, Arts. 60 and 80, as well as Arts. 258 to 262, represent a substantial elaboration of the competence of the coastal state with respect to offshore installations and structures: Convention on the Continental Shelf, 29 April 1958, 15 UST 471, TIAS 5578, 499 UNTS 311. Most of the provisions regarding coastal state competence over marine scientific research are new: Convention, Arts. 245, 252, 253. Other examples are identified in notes 3, 9,10 and 11 below, and the text annotated.

3 Convention, Art. 73(1).

4 See notes 9,10 and 11 below. 
Especially close attention is paid to the latter problem when a state is accorded enforcement jurisdiction over foreign ships with respect to pollution in areas where all ships enjoy navigation rights and freedoms, including innocent passage, ${ }^{5}$ transit passage, ${ }^{6}$ archipelagic sea lanes passage, ${ }^{7}$ and freedom of navigation. ${ }^{8}$ Pursuant to the Convention, there is at least some coastal state enforcement competence over foreign ships with respect to vessel-source pollution in internal waters, archipelagic waters, the territorial sea, straits used for international navigation, and the exclusive economic zone. ${ }^{9}$ With respect to pollution from sea-bed activities or from dumping, coastal state enforcement competence embraces all of these areas as well as the continental shelf beyond the exclusive economic zone. ${ }^{10}$ The Convention also preserves the right of the coastal state to take and enforce measures beyond the territorial sea following upon a collision or other maritime casualty which may reasonably be expected to result in major harmful consequences to its coastline or related interests. ${ }^{11}$

\section{Limitations and Vessel Release}

In both contexts, the Convention sets forth substantive and procedural limitations on enforcement competence over foreign ships. These are relatively brief with respect to fishing in the exclusive economic zone. ${ }^{12}$ Because of the impact on the rights and freedoms of navigation enjoyed by all states, there are extensive limitations not only on prescriptive competence but on enforcement competence with respect to protection and preservation of the marine environment. $^{13}$

Moreover, in both contexts, the provisions regarding the exercise of enforcement competence contain specific duties regarding vessel release. The provisions on vessel release accommodate economic and humanitarian as well as safety and environmental concerns. Detention of a ship and its crew can be costly to the owner or operator of the ship, to its crew and to those whose exports or imports are affected. Detention of crew members in a state with whose language and culture they may have little or no connection can impose severe strain and

5 There is a right of innocent passage in the territorial sea, internal waters formed by straight baselines, archipelagic waters, and certain straits. See Convention, Arts. 8(2), 17, 45, 52.

Transit passage applies in most straits used for international navigation between areas of high seas or exclusive economic zones. See Convention, Arts. 35-38.

7 See Convention, Art. 53.

8 Freedom of navigation applies in the exclusive economic zone and the high seas beyond. See Convention, Arts. 58, 86, 87.

9 Convention, Arts. 2, 19, 21, 22, 25, 27, 41, 42, 49, 52-54, 56, 211, 214, 216, 218, 220, 233, 234.

10 Convention, Arts. 208, 210, 214, 216.

11 Convention, Art. 221. See International Convention Relating to Intervention on the High Seas in Cases of Oil Pollution Casualties, 29 November 1969, 26 UST 765, TIAS 8068.

12 Convention, Art. 73.

13 Many of these are to be found in Section 1 and Sections 5 to 10 of Part XII on Protection and Preservation of the Marine Environment. But other provisions of the Convention may also contain relevant limitations. See Convention, Arts. 21(2), 22(3), 24, 26, 27, 28, 30, 32, 41, 42, 44, $45,52,53,54,56(2), 58(2), 78,92(1), 95-97,110,111,135,141,147(1), 300-302$. 
hardship on them and their families. Little is accomplished, and some harm may be done, by dumping large quantities of spoiled fish. Particularly in the case of large tankers that are difficult to stop or manoeuvre, or other ships carrying hazardous cargo, citation or formal arrest at sea for jurisdictional purposes and release on bond while the ship continues on its way without detention is often the best means to avoid a serious safety and environmental hazard.

Article 73, which deals with coastal state enforcement of fishing regulations in the exclusive economic zone, provides in paragraph 2: "Arrested vessels and their crews shall be promptly released upon the posting of reasonable bond or other security."

With respect to enforcement of pollution regulations applicable to foreign ships, Article 226(1)(a) provides, "states shall not delay a foreign vessel longer than is essential for purposes of the investigations provided for in articles 216, 218 and 220." Article 216 deals with enforcement with respect to pollution by dumping. Article 218 deals with enforcement by a port state "in respect of any discharge ... outside the internal waters, territorial sea or exclusive economic zone of that State". Article 220 deals with enforcement by a coastal state with respect to vessel-source pollution in the territorial sea or the exclusive economic zone of that state. ${ }^{14}$ Moreover, straits states that take enforcement measures with respect to foreign ships pursuant to Article 233 "must respect mutatis mutandis the provisions of' Part XII, section 7, which includes Article 226. ${ }^{15}$

14 In the context of Art. 220 and other provisions of Part XII, the reference to the territorial sea logically may be read to include ships in innocent passage not only in the territorial sea but in other waters in which there is a right of innocent passage, namely archipelagic waters and internal waters enclosed by straight baselines. (See note 5 above.)

15 Article 233 deals with enforcement of regulations regarding transit passage adopted pursuant to Art. 42. Article 42 applies mutatis mutandis to archipelagic sea lanes passage by virtue of Art. 54 . Therefore, it is reasonable to conclude that archipelagic states may take enforcement measures authorized by Art. 233 with respect to foreign ships in archipelagic sea lanes passage.

The precise effect of Art. 233 on those straits in which the applicable regime is nonsuspendable innocent passage pursuant to Art. 45, has no bearing on the application of section 7 , including Art. 226, which must be respected with respect to pollution enforcement measures against foreign ships under both Arts. 220 and 233.

While Art. 226 does not expressly refer to coastal state enforcement competence under Art. 234 in ice-covered areas, there appears to be no logical explanation for the omission of a crossreference other than mere oversight. There was no suggestion during the negotiation of Art. 234 that the duty to release an arrested vessel on bond would not apply, either directly or by virtue of incorporation into the duty under Art. 234 to have due regard to navigation. Article 234 was closely negotiated by the Canadian, Soviet and US delegations under intense political and military scrutiny, and was added relatively late in the negotiation of Part XII, after the drafting of the section 7 safeguards was largely completed by the Third Committee of the Conference. The essence of the political accommodation was to draft an article granting special competence to the coastal state for the control of pollution from ships navigating in ice-covered areas, to place the article in a new section of its own in order to make clear that it was not in a section from which Art. 233 excludes straits, and to ensure that this special competence was subject to the warship exclusion contained in Art. 236. The political sensitivity of the issue was such that little if any attention was paid to technical drafting questions, including the question of ensuring precise textual harmonization with various other provisions, either from a maritime perspective or (with respect to Art. 21(2) for example) from a coastal perspective. Even the clause "within the limits of the Exclusive Economic Zone", which logically should confirm that the special 
Paragraph 1(b) of Article 226 goes on to provide: "If the investigation indicates a violation of applicable laws and regulations or international rules and standards for the protection and preservation of the marine environment, release shall be made promptly subject to reasonable procedures such as bonding or other appropriate financial security." However, paragraph 1(c) adds an important qualification:

"Without prejudice to applicable international rules and standards relating to the seaworthiness of vessels, ${ }^{16}$ the release of a vessel may, whenever it would present an unreasonable threat of damage to the marine environment, be refused or made conditional upon proceeding to the nearest appropriate repair yard. Where release has been refused or made conditional, the flag State of the vessel must be promptly notified, and may seek release of the vessel in accordance with Part XV."17

These vessel release provisions of course contemplate enforcement proceedings against the vessel or members of the crew in the courts of the detaining state. The purpose of the bond or security is to protect against failure to appear and pay the applicable penalty. In this connection it should be borne in mind that Article 73(3) prohibits imprisonment (absent agreement to the contrary) or any other form of corporal punishment for violation of fisheries laws and regulations by a foreign vessel in the exclusive economic zone. Similarly, Article 230 provides that only monetary penalties may be imposed for pollution violations by foreign vessels within or beyond the territorial sea, except in the case of a wilful and serious act of pollution in the territorial sea. It should also be noted that Article 229 declares: "Nothing in this Convention affects the institution of civil proceedings in respect of any claim for loss or damage resulting from pollution of the marine environment."

\section{Compulsory Arbitration or Adjudication}

The relationship between these limitations and the requirements for arbitration or adjudication of disputes under section 2 of Part XV of the Convention is

competence over foreign navigation applies both in the exclusive economic zone and in waters landward of the exclusive economic zone, is not drafted as well as the clause "in all waters landward of the outer limits of its Exclusive Economic Zone" that appears in Art. 66 on the regulation of fishing for anadromous species, notwithstanding the major roles played by the same three delegations in the negotiation of Art. 66.

Article 219 sets forth the duties of port states with respect to the seaworthiness of vessels. (Footnote added.)

17 While the problem addressed by this qualification is more readily imagined in the case of a vessel arrested for a pollution violation (e.g. a tanker carrying hazardous cargo), it might also arise in the case of a vessel arrested for a fishing violation. While the qualification does not apply literally in the latter case, an international tribunal convinced that a fishing vessel poses an unreasonable threat of damage to the marine environment is unlikely to order the vessel to be released with no assurance that the threat will be mitigated. That conclusion might be rooted in Art. 192, which sets forth the basic duty of all states to protect and preserve the marine environment, or in the duties of the flag state under Art. 217. 
central to the overall balance achieved. Subject to certain exceptions, any dispute concerning the interpretation or application of the Convention, not settled by other means, "shall ... be submitted at the request of any party to the dispute" to the court or tribunal having jurisdiction under the Convention. ${ }^{18}$ For this purpose, states may file declarations choosing the new International Tribunal for the Law of the Sea established by the Convention, the International Court of Justice, arbitration or, for enumerated types of disputes, a special form of arbitration. ${ }^{19}$ If the parties have accepted the same procedure, it may be submitted only to that procedure except as otherwise agreed. ${ }^{20}$ If the parties have not accepted the same procedure, or if the dispute is not covered by a declaration in force for one of the parties, arbitration is the applicable procedure. ${ }^{21}$

The section 2 procedures apply only to parties to the Convention, ${ }^{22}$ except as otherwise provided in the Convention or some other agreement. ${ }^{23}$ Moreover, if the parties to the dispute have agreed in another instrument that such dispute shall, at the request of any party to the dispute, be submitted to a procedure that entails a binding decision, that procedure applies in lieu of the procedures provided for in Part XV unless otherwise agreed. ${ }^{24}$

\section{Limitations}

Paragraph 1 of Article 297 enumerates the circumstances in which disputes with regard to the exercise by a coastal state of its sovereign rights or jurisdiction are subject to compulsory arbitration or adjudication under section 2 ; they may be summarized as follows:

- alleged coastal state violations of provisions regarding freedoms and rights of navigation, overflight, laying of submarine cables and pipelines, and related uses;

- alleged flag state violations in the exercise of such freedoms, rights and uses; or

- alleged coastal state violations of specified international rules and standards for the protection and preservation of the marine environment.

In addition, pursuant to Article 298(1)(b), a state may, if it wishes, file a written declaration that it does not accept compulsory arbitration or adjudication under section 2 with respect to "disputes concerning law enforcement activities in

Convention, Art. 286.

Convention, Art. 287(1).

Convention, Art. 287(4).

Convention, Art. 287(3) and 287(5).

Only states and certain other entities with international juridical personality, such as the European Community and self-governing associated states, may be party to the Convention: Convention, Arts. 305-307; Ann. IX.

In this connection, it may be recalled that only states may be parties to cases before the International Court of Justice: Statute of the International Court of Justice, Art. 34(1).

Convention, Art. 282. 
regard to the exercise of sovereign rights or jurisdiction excluded from the jurisdiction of a court or tribunal under article 297, paragraph 2 or 3". The absence of a cross-reference to paragraph 1 of Article 297 was deliberate. Paragraph 2 of Article 297 relates to marine scientific research; paragraph 3 provides that "the coastal state shall not be obliged to accept the submission to [arbitration or adjudication under section 2] of any dispute relating to its sovereign rights with respect to the living resources in the exclusive economic zone or their exercise." 25

The import of these provisions is that coastal state enforcement competence over foreign ships for pollution enforcement purposes is not excluded, or subject to exclusion, from compulsory arbitration or adjudication, especially where that competence relates to ships exercising navigation rights or freedoms recognized by the Convention. Such a case would be subject to arbitration or adjudication in accordance with Article 297(1) and, in particular, would normally involve an allegation that the coastal state has violated provisions regarding the freedoms and rights of navigation. On the other hand, the situation with respect to coastal state fisheries jurisdiction in the exclusive economic zone is, in essence, the reverse.

\section{Vessel Release under the General Dispute Settlement Provisions}

Even in the absence of a special procedure for securing compliance with the provisions of the Convention regarding vessel release, the flag state could bring the matter before a tribunal having jurisdiction under the general dispute settlement provisions of the Convention, namely section 2 of Part XV. The relief requested could be release of the vessel and crew as required by the Convention. Pursuant to Article 290, the flag state could also request the tribunal to prescribe provisional measures. The provisional measures requested could be release of the vessel and crew on the grounds that their detention pendente lite constitutes an irreparable injury. ${ }^{26}$ If the tribunal "considers that prima facie it has jurisdiction" it "may prescribe any provisional measure which it considers appropriate under the circumstances to preserve the respective rights of the parties to the dispute or to prevent serious harm to the marine environment, pending the final decision". The parties must comply promptly.

Urgency is the basic characteristic of situations that may require a tribunal to

While Arts. 61 to 73 of the Convention contain detailed conservation, management and enforcement limitations on coastal state authority with respect to living resources in the exclusive economic zone, such limitations are not specified with respect to the living resources of the territorial sea or, by virtue of Arts. 68 and 77(4), with respect to sedentary species of the continental shelf. The absence of an express reference to areas other than the exclusive economic zone in Art. 297(3)(a) presumably reflects this fact.

26 A relevant precedent would be the provisional measures of the International Court of Justice directing Iran to ensure the immediate return of US premises and release of US detainees: United States Diplomatic and Consular Staff in Teheran (US v Iran) [1979] ICJ Rep 7, pp. 20-21 (Provisional Measures Order of 15 December). 
prescribe provisional measures. But an arbitral tribunal may be the only forum with jurisdiction under section 2 of Part XV and the declarations of the parties. It can take several months to constitute an arbitral tribunal, particularly if the state being sued is less than enthusiastic. ${ }^{27}$ For this reason, Article $290(5)$ provides that, failing agreement between the parties on another forum within two weeks from the date of the request for provisional measures:

"Pending the constitution of an arbitral tribunal to which a dispute is being submitted [under section 2], ... the International Tribunal for the Law of the Sea ... may prescribe ... provisional measures ... if it considers that prima facie the tribunal which is to be constituted would have jurisdiction and that the urgency of the situation so requires. Once constituted, the tribunal to which the dispute has been submitted may modify, revoke or affirm those provisional measures ...."

\section{The Vessel Release Procedure}

The alternative special procedure for vessel release under Article 292 of the Convention can be understood as an attempt to define an additional procedure that is different from, and presumably better tailored to the specific task, than that which is available under the general dispute settlement provisions of the Convention (including those concerning provisional measures).

Article 292 is one of only two articles in Part XV that does not contain the word "dispute". ${ }^{28}$ While one party's demand for release as required by the Convention, and the other party's failure to release, normally would be understood to constitute a dispute concerning the interpretation or application of the Convention, the absence of the word "dispute" suggests that the nature of Article 292 is different from other provisions of Part XV. Its relationship to those provisions must be analysed with care.

What is submitted to the court or tribunal under Article 292 is "the question of release from detention". That question may be presented when "it is alleged that the detaining State has not complied with the provisions of this Convention for the prompt release of the vessel or its crew upon the posting of a reasonable bond or other financial security". The court or tribunal "shall deal only with the question of release, without prejudice to the merits of any case before the appropriate domestic forum against the vessel, its owner or its crew". The duty of the detaining state is to "comply promptly with the decision of the court or tribunal concerning the release of the vessel or its crew ... [u]pon the posting of the bond or other financial security determined by the court or tribunal".

The competence of a court or tribunal under Article 292 is extremely limited. The sovereign rights or jurisdiction of the detaining state to arrest, try or punish 
the vessel or crew are not at issue. ${ }^{29}$ The existence and exercise of prescriptive, enforcement or adjudicative competence are not at issue. Liability for damages is not at issue. While the remedy of release, even without bond, would be a proper exercise of the power to prescribe provisional measures under Article 290 in any case where appropriate to preserve the respective rights of the parties pendente lite, under Article 292 the question of release may be submitted only if the Convention requires prompt release upon the posting of a reasonable bond or other financial security. The relevant language is drawn from the release provisions of Articles 73 and 226.

Because it limits significantly what is at stake, the restricted competence of a court or tribunal under Article 292 may permit greater speed and flexibility. This is in fact the case.

Article 290 requires that a request for provisional measures be made in connection with a dispute submitted to a court or tribunal having jurisdiction under section 2 and the declarations of the parties. In this connection, a court or tribunal prescribing provisional measures must consider "that prima facie it has jurisdiction" $" 30$ over the parties and the dispute under the Convention. ${ }^{31}$ That question, as well as the question of the need for provisional measures and the urgency of that need, might be affected by the question of whether local remedies have been exhausted in municipal courts. ${ }^{32}$ The procedure may be further complicated if the case involves coastal state jurisdiction and the respondent

29 The release provision of Art. 226(1)(b) assumes that the investigation by the detaining state indicates that applicable regulations have been violated by the ship or crew.

30 At least in textual terms, this is a more stringent requirement than that articulated by the International Court of Justice, which has indicated provisional measures when the instrument invoked by the applicant appears prima facie to afford "a possible basis upon which the jurisdiction of the Court might be founded": Fisheries Jurisdiction (UK v Iceland; FRG v Iceland), [1972] ICJ Rep 12, 15-16 (Interim Protection Order of 17 August) (citation to companion opinion omitted). This standard, albeit without the word "possible", has been repeated by the Court in numerous cases since then. It was analysed by the late Judge Jiménez de Aréchaga in "International Law in the Past Third Century", (1978) 159 Rec. des Cours 1, 161, and by Judge Schwebel in Military and Paramilitary Activities in and against Nicaragua (Nicaragua v US), [1984] ICJ Rep 169, 206-207 (Provisional Measures Order of 10 May) (Sep. Op. Schwebel, J.).

31 Where the dispute has been submitted to an arbitral tribunal that has yet to be constituted, the International Tribunal for the Law of the Sea may not prescribe provisional measures unless "it considers that prima facie the tribunal which is to be constituted would have jurisdiction".

See Convention, Art. 295. Where release of a vessel or crew is the provisional measure requested, the respondent might argue that the question of release and bond is currently before its own trial or appellate courts, and that municipal courts should be given a reasonable time to arrive at a decision. In the Interhandel case, the International Court of Justice, observing that there was no indication that US courts would reach a speedy conclusion, declined to indicate provisional measures in anticipation of a final judgment in the US courts adverse to Swiss interests: Interhandel (Switzerlandv US), [1957] ICJ Rep 105, 112 (Interim Protection Order of 24 October). While the Interhandel case is certainly distinguishable from a situation in which a ship or its crew are being detained, it does illustrate the fact that proceedings in municipal courts may be relevant to the question of whether and when to prescribe provisional measures. 
exercises its right to request a preliminary determination that the claim constitutes an abuse of legal process or prima facie is unfounded. ${ }^{33}$

Article 292 does not require that a request for vessel release be made in connection with a dispute submitted to a court or tribunal having jurisdiction under section 2 and the declarations of the parties. Nor does it require that the application for release be submitted to a court or tribunal that has jurisdiction under the other provisions of section 2 . If the parties fail to agree on a forum within 10 days from the time of detention, ${ }^{34}$ the application for release may be submitted "to a court or tribunal accepted by the detaining State under article 287 or to the International Tribunal for the Law of the Sea". This gives the applicant a reasonable choice and helps avoid jurisdictional issues. ${ }^{35}$

Although urgency is a basic characteristic of a situation requiring provisional measures, Article 290 refers explicitly to this fact only in what is arguably a negative sense. In a case in which the International Tribunal for the Law of the Sea has been requested to prescribe provisional measures pending the constitution of an arbitral tribunal with jurisdiction over the dispute, the Tribunal may do so only "if it considers ... that the urgency of the situation so requires". Although the need for urgent consideration of a request for provisional measures is implicitly recognized by the fact that the International Tribunal for the Law of the Sea is authorized to prescribe provisional measures soon after it receives the request if an arbitral tribunal with jurisdiction over the dispute is not yet constituted, by the fact that a five-member chamber of the International Tribunal for the Law of the Sea is authorized to prescribe provisional members if the Tribunal is not in session or a quorum is not present, ${ }^{36}$ and by the procedural priority accorded requests for provisional measures in the Rules of Court of the International Court of Justice, ${ }^{37}$ the Convention does not explicitly command urgency or priority for requests for provisional measures.

Article 292 expressly permits an application for release to be filed after 10 days following detention and requires that the court or tribunal deal with the application for release "without delay". Insofar as vessel release proceedings are

35

Convention, Art. 294

The waiting period before the International Tribunal for the Law of the Sea may indicate provisional measures is "two weeks from the date of the request for provisional measures" in a case where an arbitral tribunal with jurisdiction over the dispute is not yet constituted: Convention, Art. 290(5). In this regard it is interesting to note that the question of release may be submitted to the International Court of Justice under Art. 292 if the respondent has accepted the jurisdiction of the Court in its declaration under Art. 287. Under Art. 290, an application for provisional measures may not be submitted to the Court unless it has jurisdiction over the dispute; the Court has jurisdiction over the dispute under Art. 287 only if both the applicant and the respondent have accepted its jurisdiction in their declarations.

Convention, Ann. VI, Art. 25(2).

The Rules of Court of the International Court of Justice provide that a request for provisional measures "shall have priority over all other cases" and that the Court "shall be convened forthwith for the purpose of proceeding to a decision on the request as a matter of urgency". 
concerned, there is no lack of persuasive arguments that Article 295 does not require exhaustion of local remedies, that Article 294 regarding preliminary proceedings is not relevant, and that other provisions of Part XV that might frustrate or delay the proceedings are inapposite. But the analysis is simplified by the reference to the 10-day period and the command to proceed "without delay" and "deal only with the question of release". These clauses, as well as the absence of the term "dispute", provide the court or tribunal with an intrinsic textual basis in Article 292 itself for concluding that such requirements do not apply to vesselrelease applications, and minimize the need to engage in complex analyses of the meaning, scope and purpose of other provisions of Part XV.

\section{Applications "on behalf of" the Flag State}

An application for release may be made only "by or on behalf of the flag state of the vessel" ${ }^{38}$ Article 292 is the only provision of the Convention that contains such a formulation. In order to appreciate its import, one may compare the two alternatives it offers.

Under ordinary concepts of standing, there is nothing unusual about the notion that an application for release of the ship or the crew may be made by the flag state. The exclusive standing accorded the flag state in this regard is also not particularly surprising.

In connection with an application made by it, the flag state is free to select representatives, agents or counsel of its choice to appear before a court or tribunal. They may be, and frequently are, private attorneys hired for the specific case, rather than government officials. There is no prohibition on the owner or operator of the ship, or any other person, assisting the flag state in the selection or remuneration of representatives, agents or counsel who appear in connection with an application for release made by the flag state. The fact that they are authorized to appear will presumably be indicated by naming them in official documents transmitted to the court or tribunal in connection with the particular proceedings instituted by the application.

Redundancy should not be presumed. A text that provides that an application for release may be made "by or on behalf of" the flag state should be interpreted to give meaning to the fact that it offers alternatives. The words "on behalf of" provide an option that is not provided by the word "by". One would deny those words alternative effect were one to interpret the term "on behalf of" to mean only that the flag state may name a specific individual or individuals to appear on its behalf in official documents transmitted to the court or tribunal in connection with each application for release. The flag state can (and to some degree must) do that in actions brought "by" it.

In this connection, it should be recalled that an application for release under Article 292 may be brought before a court or tribunal that does not have 
jurisdiction over disputes between the flag state and the respondent state under the other provisions of Part XV, that only the question of release may be addressed by the court or tribunal, and that urgency is the essence of the release procedure. This suggests that a flag state might rationally decide that a governmental decision in connection with each application for release is unnecessary and may entail undesirable delay and expense. It might also prefer a procedure that minimizes the expenditure of governmental resources, and that leaves it to the private parties concerned to pursue release. In that connection, the private party would have to weigh the costs to it of vessel release proceedings in assessing its willingness to provide a bond or financial security in the amount fixed by the detaining state.

To have real alternative effect, the words "on behalf of" should be understood to permit the flag state to dispense with the need for official communications from its government in connection with each application for release. The flag state, if it wishes, may designate in advance natural or juridical persons, by name or by class, who are authorized to bring applications for release on its behalf. It might designate, for example, the owners or operators of detained vessels, a shipping association, or a labour union. Since no application for release may be made on behalf of the flag state against its will, the flag state may change, qualify or withdraw its designations.

It should be sufficient that the court or tribunal have in its possession an authentic copy of the law, regulation, or other official act of the flag state designating the persons or class of persons authorized to bring an application for release on its behalf, and documentation establishing that the ship is registered in the state concerned and that the person making the application for release on behalf of the flag state is a person referred to in the law, regulation, or other official act of the flag state. In addition, a person making an application on behalf of the flag state might be required to certify that a copy of the application and supporting documentation has been delivered to a government minister or other competent official of the flag state, and to indicate the name and title of the official concerned and the date, time and place that delivery was effected. The flag state could of course impose additional notice and information requirements on its designees.

Such an approach would be consistent with the negotiating history of Article 292. The United States and certain other states supported access by private parties to dispute settlement tribunals under the Convention in a number of circumstances, including vessel release. They were successful in the case of deep sea-bed mining. ${ }^{39}$ They were successful in establishing that the International Tribunal for the Law of the Sea is open to entities other than States Parties pursuant to any agreement conferring jurisdiction on the Tribunal. ${ }^{40}$ By agreeing to the "by or on behalf of" formula, they compromised with those reluctant to 
accept private access on a text designed to permit the flag state to authorize private access in fact while maintaining the form of a state-to-state proceeding.

Precisely what was negotiated might be considered in the light of Article 190 of the Convention. The relationship between a deep sea-bed mining company and its sponsoring state under Part XI of the Convention is analogous to the relationship between a shipowner and the flag state, but was not conceived to be as comprehensive in part because the mining company has a direct contractual relationship with the Sea-Bed Authority under the Convention. Nevertheless, even in that context, it was necessary to include provisions in Article 190 dealing with the right of the sponsoring state to intervene, and the right of a respondent state to request the intervention of the sponsoring state, where a private mining company is a party to a dispute. The Article also reveals the sensitivity of certain states to the idea of being sued by a private party in an international tribunal: if the sponsoring state does not intervene at the request of the respondent state, the respondent state "may arrange to be represented by a juridical person of its nationality".

In the case of vessel release, had the owner or operator of a ship been accorded a right of direct access, the flag state probably would have been accorded a right of intervention and the detaining state probably would have been accorded a right at least to request such intervention. The real choice therefore was between a system in which there is effective private access unless the flag state and perhaps the respondent state objects, and a system in which there is effective private access if the flag state affirmatively authorizes it. The Convention opts for the latter and, by maintaining the form of an action "on behalf of" the flag state, accommodates the sensitivities of respondent states.

This system poses no jurisdictional problems for the International Tribunal for the Law of the Sea. In principle, it is not closed to private parties. The Convention is its constituent instrument, and the Convention authorizes it to hear vessel-release applications made by or on behalf of the flag state.

There is, however, a question concerning vessel-release applications filed with the International Court of Justice. Because only states may be parties to cases before the Court, ${ }^{41}$ it may be more sensitive to the questions posed by applications brought "on behalf of' the flag state. On the other hand, the Court might see the emergence of this formula in a globally negotiated and widely ratified Convention as a timely invitation by states to allow some flexibility in interpreting the Statute in this regard.

\section{The Private Bar}

It is too early to tell how often the vessel release procedures of the Convention will be used. Because of the delays inherent in constituting an arbitral tribunal, it is likely that virtually all applications will be made either to the International 
Court of Justice or to the International Tribunal for the Law of the Sea. Of the two, the Tribunal is available to all applicants, while the Court is available only if the detaining state accepted the jurisdiction of the International Court of Justice in its declaration pursuant to Article 247.

If vessel-release applications are referred to a Chamber of the Tribunal in much the same way as requests for provisional measures, ${ }^{42}$ the result could well be a forum that is more readily available. It remains to be seen whether the Tribunal's rules may facilitate the vessel-release procedure along these lines, or whether the parties to the Convention, in allocating expenses of the Tribunal among themselves, will create incentives for the use of chambers.

It is also too early to tell how many flag states will authorize vessel owners or others to make applications for release on their behalf. In the case of major flag states the answer may depend on the advice they receive from the shipping attorneys they consult. It is by no means clear that many of those attorneys are aware of the opportunity presented by such legislation to help shipowners enjoy the benefits of the vessel-release remedy without the need for a decision in each case by the flag state, and the concomitant opportunity to relieve the flag state of the financial and other burdens associated with the need to bring each release proceeding itself.

The urgency associated with vessel release suggests that lawyers will be sought who are in a position to file applications quickly, persuade a tribunal to proceed quickly, and of course win. When the application is filed by a private person "on behalf of' the flag state, it is likely that private attorneys will be hired and paid by that person. But this may be the case, at least to some extent, even where the application is made "by" the flag state. Detaining states are also free to hire private counsel if they wish.

The legal questions likely to arise most frequently concern the amount of the bond or other financial security that must be posted and, at least on occasion, whether more time is reasonably required for investigation prior to release. Particular cases may pose the question of whether release of a ship has been properly refused or made conditional on proceeding to a repair yard because the ship is not seaworthy or poses an unreasonable threat of damage to the marine environment. Some attorneys in law enforcement agencies of government and some members of the private bar specializing in admiralty, criminal law or environmental law may have considerable experience in dealing with these kinds of questions.

There is no reason to doubt that the German Government will permit parties before the Tribunal to be represented by counsel of their choice, without regard to the country in which counsel is licensed to practise law, if any. Counsel and their assistants presumably will be permitted to arrive in Hamburg some time before a case is scheduled to be heard, to lease residential and office space and 
amenities, and to remain and work in Hamburg while the case is under consideration and for a reasonable time thereafter.

An interesting question that emerged in discussions organized by the Stiftung Wissenschaft und Politik in Ebenhausen in the spring of 1995 is whether foreign counsel, not otherwise authorized to practise law in Hamburg, will be permitted to maintain an office in Hamburg even when they are not working on a case before the International Tribunal, if the purpose of that office is to advise clients with respect to the Tribunal and represent them before the Tribunal. If so, it would be interesting to consider what restraints, if any, would apply to their efforts to obtain clients with business before the Tribunal.

The legal argument that such activity should be permitted would, in principle, reflect a functional point of view regarding regulation of the bar: counsel is not, from the Hamburg office, practising German law (or any other municipal law) or appearing before German courts (or other municipal courts) or seeking German clients (at least as such), but is maintaining an office solely for the purpose of practising public international law before an International Tribunal located in Hamburg where, with few exceptions, only states may be parties to cases. The legal argument that such activity should not be permitted would, in principle, reflect a nationalist point of view regarding regulation of the bar: only lawyers licensed by Germany (or its European Union partners) may set up a law office in Germany.

Either argument is consistent with territorial sovereignty. No one argues that foreigners may operate a law office in Hamburg without the consent of the competent German authorities. The question is whether Germany ought to consent or has consented, by treaty or otherwise.

It is probably a mistake to analyse this question in terms of Germany's international obligations as such, present or proposed. Few if any states are likely to press Germany to assume such obligations. For some time, the question is likely to be more theoretical and symbolic than real. Some states are likely to watch and wait before agreeing to submit cases to the Tribunal or accepting its compulsory jurisdiction beyond the matters specified in the Convention, namely vessel release, provisional measures, and deep sea-bed mining disputes. Without the prospect of attracting clients, lawyers are unlikely to rush in.

At least for the present, the real question is whether Germany wishes to promote the development of the idea that Hamburg is a global centre for legal activity related to the international law of the sea, using the presence of the International Tribunal as a focal point. Some states find it in their interests to adopt special entry, visa, and customs procedures for foreign shipping and products and related personnel and activities in order to develop trade in their ports. A similar logic may apply to foreign lawyers with an interest in practising before the Tribunal, or perhaps even with a broader interest in the sea.

If there are free ports, there may be free cities with respect to the international law of the sea and perhaps some international aspects of maritime law. As its name and history suggest, the Free and Hanseatic City of Hamburg might be a logical place to consider the idea. 